\title{
Application of Markov chain method for landscape scenario building
}

Scenarios used as a tool in the fields of landscape and spatial planning are gaining popularity, as they enable the vivid representation of a probable or the desired future state of a certain area. Scenarios are usually defined trough a process that combines a differing share of intuition and scientific knowledge. The preference of scenarios based on scientific knowledge and defined methods over intuitively prepared scenarios are the evident course of events and the time line and not just the initial and final situation. The article introduces Markov chain method and its use for scenario building. It compares the applicability and reliability of the results of the Markov chain method with a more simple method of linear extrapolation and will shortly present the findings regarding Markov's chain method use for the presentation of future spatial changes and processes.

Key words: landscape scenarios, scenario methodology, Markov chain method 


\section{Introduction}

In the field of landscape planning the term scenario refers to various probable accounts or alternative assumptions that represent future landscapes. Changes of landscape are usually presented trough changes of land use that are consecutively observable trough a changed land cover pattern (Steinitz et al., 2003). Herman Kahn introduced the term scenario for longterm visions of the future in the year 1950. The term in its broadest sense combines various techniques and studies aiming at investigation of the future, such as: trend analysis, variant analysis, prognoses and strategic thinking (Shearer, 2005). The broadened use of scenario results, also in the number of various definitions of scenarios that are adjusted to an individual form and the usage of scenarios. Van den Berg and Veeneklaas (1995: 11) introduced the following definition: "Scenario is a description of the current situation, of a possible or desirable future state as well as a series of events that could lead from the current state of affairs to this future state". Another description that also defines landscape scenarios and their role in the planning process, was presented by Shoemaker (1993: 196): "Scenarios stimulate creative ways of thinking that help stakeholders break out of established patterns of assessing situations and planning actions, so that they can better adapt to the future". Both definitions considered together explain the contents of scenario presented in this article and their influence on stakeholders.

Scenario building can be either founded entirely on an intuitive mental process, so called black box, or it can be defined trough exact procedures or models. The researchers usually prepare scenarios based on different amounts of both kinds of knowledge. The benefits of a scenario prepared, following a certain model or a method is the evidentiary course that leads from the starting point to the final state or the result in contrast to an intuitive procedure, where only the starting and end points are visible.

The Markov chain method was used in a presented process of scenario building as a base for the representation of the dynamics of change that could evolve in a certain landscape. The development of landscape in the scenario is defined trough probable changes of land use, which were calculated, based upon Markov chains and complemented by the expected influences of different driving forces and developmental factors. As a driving force certain policies were considered. These policies are important from the conservation point of view (protected areas, reserves, where restrictions are precise and compulsory) and from a developmental point of view (incentives, defined praxis of land management). In defining landscape changes the laws that determine the transitions between different types of land use have to be considered, for instance: abandoned pastu- res don't turn into a forest in one sequence but turn gradually trough the process of overgrowth, the change from agricultural land use to a building lot is made in a sequence and is usually irreversible. The time needed for the transition from one land use into other land use depends on the pressure for change and upon specific circumstances.

Markov chains are known in different scientific fields; however they are used more in the natural sciences but also in social sciences. In the so called spatial sciences, Markov chains are used to explain problems of movement in space or in time, respectively proceeding from one state to another. Markov chains are used for describing, analyzing and the forecasting of the development of different features, such as: employment, migration, growth or decline of urban systems and landscape changes (e.g. Omladič, 1993; Mežan, 1995). In the field of spatial development a research study was conducted for the Ljubljana urban area (Lawson, 1977). Although the research is of an older issue, it is useful as a case study of the application of Markov chains in forecasting the development in a specific (urban) area. The example of scenario building based on Markov chains is the research performed by Stadelmann, and Weiss (2007) called Modelling of future land use in the Surselva area, a similar approach was used by Tappeiner et al. (2007) and in the scope of Slovenia by Kovačič et al. (2007).

\section{Description of the method}

\subsection{Markovian models}

"Stochastic or probable processes are processes that are changing through time or space according to laws of probability. Many real-life processes have the properties of stochastic processes, so the knowledge of their functioning is of crucial importance in understanding the actual processes" (HudoklinBožič, 1999: 5). Markov chain, Markov models or Markovian models and hidden Markov models belong in the context of stochastic processes. The basic characteristics of Markov models were introduced by Andrey Andreyevich Markov (18561922), a Russian mathematician, who studied the theory of numbers, the probability theory and is best known for his work on the theory of stochastic processes (Basharin et al., 2005).

The basic Markov process is a Markov chain, the sequence $x_{1}, x_{2}, x_{3}, \ldots$ of discrete random variables, where the first following variable $x_{n}$ depends solely on the value of the preceding variable, $x_{n-1}$ at $n=2,3,4, \ldots$ (Lawson, 1970). In a Markov process the conditional probable distribution of variable $x_{m}$ depends only on the last known (usually present) state and is independent of past states. Markov processes "have no memory", to predict the future of the process, only the present and not the past is important, future states will be defined trough 
a probabilistic and not by a deterministic process. If a certain process is Markovian, the Markov property has to be valid for its space of states (Hudoklin-Božič, 1999):

A process is Markovian in the discrete time, if for optional time $l<m<n$ and for the conditional probability of the random variable $x_{n}$, the present state fully captures all the information that could influence the future evolution of the process.

$\operatorname{Px}_{\mathrm{n}}\left(\mathrm{x} \mid \mathrm{X}=\mathrm{y}, \mathrm{X}_{1}=\mathrm{z}, \ldots\right)=\operatorname{Px}_{\mathrm{n}}\left(\mathrm{x} \mid \mathrm{X}_{\mathrm{m}}=\mathrm{y}\right)$

Markov chains are Markov processes in with discrete states in discrete time, also Markov processes with discrete states in continuous time. Markov chains can have finite or infinite number of states. A Markov chain is a set of discrete random variables $\left\{x_{n}\right\}, n=0,1, \ldots$, that have the following property: if the value of $x_{\mathrm{m}}$ in optional time $m$ is known, in a later moment $m+n$ the probable distribution $x_{m+n}$ is absolutely defined (Hudoklin-Božič, 1999).

$P\left(X_{m+n}=j \mid X_{m}=i, X_{m-1}=h, X_{m-2}=g, \ldots\right)=P\left(X_{m+n}=j \mid X_{m}=i\right)$

Markov chains are homogenous in time if the conditional probability P depends only on the length of the time interval or period $n$ and not of the time $m$. The following relationship holds:

$P\left(X_{m+n}=j \mid X_{m}=i\right)=P\left(X_{n}=j \mid X_{0}=i\right)$

$\mathrm{m}=1,2 \ldots ; \quad \mathrm{n}=1,2, \ldots$

The conditional probability, that at the beginning of the observation the state $i$ and after time $n$ the state $j$ were occupied, is called the probability of transition from state $i$ to state $j$ in time $n$ (in $n$ sequences) and is marked with the symbol $\mathrm{p}_{\mathrm{ij}}^{(\mathrm{n})}$.

$\mathrm{p}_{\mathrm{ij}}^{(\mathrm{n})}=\left(\mathrm{X}_{\mathrm{m}+\mathrm{n}}=\mathrm{j} \mid \mathrm{X}_{\mathrm{m}}=\mathrm{i}\right)$

The probability of transition in one sequence $p_{i j}$ is the probability that a variable changes from state $i$ in one unit of time to state $j$ respectively, its value will change from $i$ to $j$. A finite Markov chain with a set of states $S=\{0,1, \ldots N\}$ it is a $(N+1)^{2}$ probability of transition from one state to others. These probabilities are most clearly presented in a matrix form:

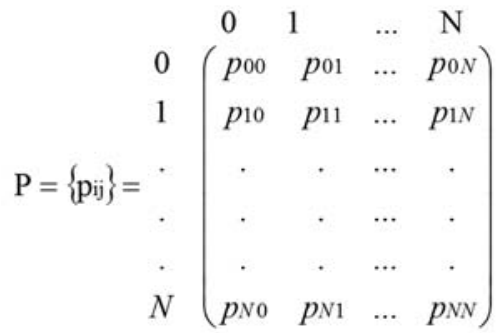

Matrix $P$ is called a transition probability matrix; the initial states are changing in rows, the end states in the columns of the matrix. A transition probability matrix holds all necessary information about the transition of the chain of states in the set of states $S$. The matrix is stochastic, meaning that all the element are non-negative and the sum in each row is equal to 1 (probability is 1 ), the transition probability matrix is square (Hudoklin-Božič, 1999). If matrix $P$ is a constant, then the Markov chain is homogenous, the transitional probabilities are stationary.

For elements of the matrix $P$ it holds:

$$
\sum_{j} p_{i j}=1 \quad 0 \leq \mathrm{p}_{\mathrm{ij}} \leq 1 \quad \mathrm{i}=1,2, \ldots \mathrm{N} .
$$

Matrix $P$ and its initial distribution of probability

$$
\mathrm{P}(0)=\left(\mathrm{p}_{\mathrm{i}}^{(\mathrm{n})}, \mathrm{p}_{\mathrm{i}}^{(\mathrm{n})}, \mathrm{p}_{\mathrm{i}}^{(\mathrm{n})}\right) \quad 0 \leq \mathrm{p}_{\mathrm{i}} \leq 1 \quad \mathrm{i}=1,2, \ldots \mathrm{N}
$$

completely define the probability property of the homogenous Markov chain. The vector:

$\mathrm{p}(\mathrm{n})=\left(\mathrm{p}_{1}{ }^{(\mathrm{n})}, \mathrm{p}_{2}{ }^{(\mathrm{n})}, \mathrm{p}_{\mathrm{N}}{ }^{(\mathrm{n})}\right) \quad 0 \leq \mathrm{p}_{\mathrm{i}} \leq 1 \quad \mathrm{i}=1,2, \ldots \mathrm{N}$

tells what is the probability of the system to be in a state $i$ after $n$ number of sequences (Jamnik, 1987).

\subsection{Scenario building based on Markov chain method}

From the basic characteristics of Markov chains, we turn to the application of the method for the scenario building of the test area Godovič-Črni Vrh and Idrija municipality. The research was performed as a part of a doctoral dissertation Influence of landscape scenarios on stakeholder attitudes and actions ${ }^{[1]}$ (Gantar, 2009). The main interest in the use of Markov chains was the definition of transition probability matrix for the test area on the basis of the principal matrix $P$. The definition of the transition probability matrix was elementary for the examination of the probabilities of land use changes in the test area, and the acreages of changing land uses within a certain period. This method was also selected due to the characteristics of spatial data attainable for the test area. The guiding principle for the selection of certain spatial data was their spatial precision and reciprocally comparable data for (at least) two periods.

The evaluation of changes in the landscape by land use categories the information on conversion elasticity (i.e. mutual convertibility of land use categories) and on land use transition sequences is required (Lawson, 1970). Conversion elasticity indicates the ability of land use to change into certain other 


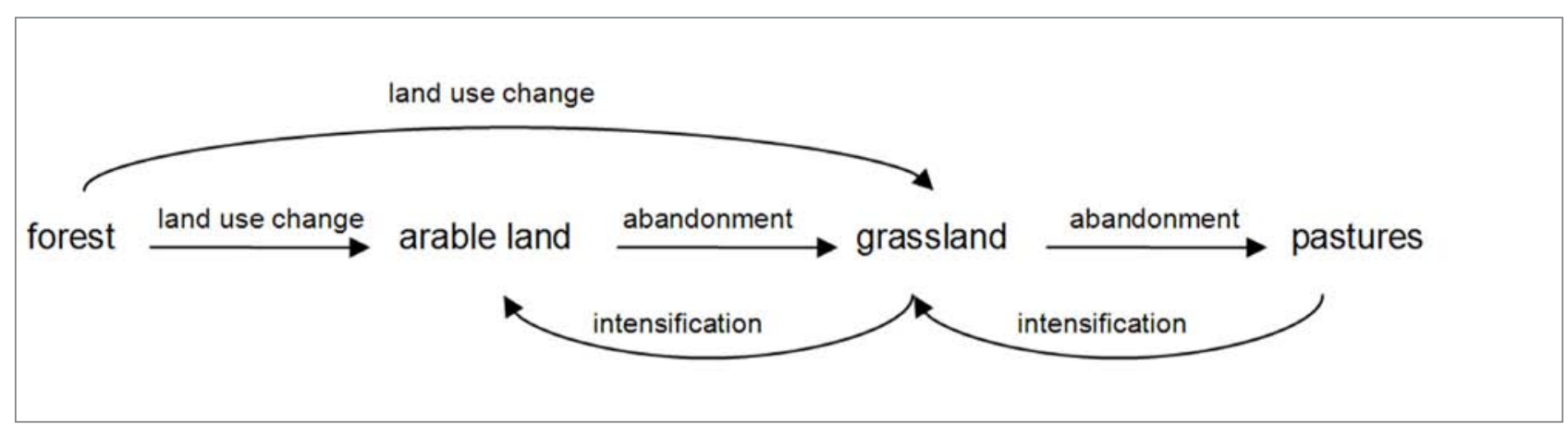

Figure1: Scheme of land use changes in sequences.

land use and also the ability to turn back to the initial land use. Usually the land uses with high inserted capital and work, e.g. housing or permanent crops are rarely changed and are in need of greater time periods to change, if at all. Other land uses, e.g. grasslands can be transformed relatively quickly into urban use, the changes between forested areas and grasslands respectively to agricultural land and back are however continuous, but beyond the forest border. The conversion elasticity is defined on a scale from 0 (easy transition) to 1 (irreversible transition). The value is usually defined based on expert knowledge and observations (Figure 1).

Firstly the assumption of constant changes of land use categories was examined by the application of the linear extrapolation method. The changes of land use categories between the years 1998 and 2007, acquired from the cadastre of actual agricultural land use (Ministry of agriculture, forestry and food, 1998, 2006a) were directly extrapolated - transferred to the future and the values of the changes for the next 15 year period were calculated based on the assumption of the constant changing of land use (Table 1).

Land use changes estimated by the use of linear extrapolation can only be used as an orientation, and is most of all significant as a warning of errors resulting from the simple transformati- on of previous trends in forecasting the future. The presented results are even less reliable, as the acquired data that has a relatively short time period. In this case the linear extrapolation means that the linear proceedings of the trends that taking place between the years 1998 and 2006, to a specific future period. The calculations were made in steps and the changes in land use were presented for each single year; in Table 1 only the initial and final area for each land use are presented. Based on these results, we can say that the use of the linear extrapolation method is not suitable to forecast land use changes, some areas of certain land use categories in the presented case have already become negative. To conclude: the transitions of land use categories usually aren't linear. However, based on the data for only two years in a relatively short time period, we can not define the characteristics of the transitions in greater detail.

\subsection{The selection and processing of the input data for scenario building}

The first step in the scenario building process was the decision for the appropriate input data, which would be suitable for the application of Markov chain method. The data can be acquired from differed sources. For land use analysis on a relatively small test area, an in-depth spatial precision is required so the spatial

Table 1: Estimation of land use changes for specific land use (15 year interval) using the method of linear extrapolation.

\begin{tabular}{lrr}
\hline Land use $\left(\mathrm{m}^{2}\right)$ & Year 2006 & Year 2021 \\
\hline Fields and gardens & $316,420.12$ & $-240,675.08$ \\
\hline Extensive orchards & $110,284.32$ & $127,452.72$ \\
\hline Permanent grassland & $16,980,397.73$ & $17,043,431.18$ \\
\hline Overgrown areas & $677,216.96$ & $699,262.70$ \\
\hline Uncultivated agricultural land & $34,839.45$ & $-16,810.65$ \\
\hline Agricultural land with forest trees & $146,574.96$ & $-155,480.19$ \\
\hline Trees and shrubs & $562,868.21$ & $860,028.86$ \\
\hline Forest & $62,983,163.81$ & $63,326,461.61$ \\
\hline Built and related sites & $2,369,026.25$ & $2,244,325.85$ \\
\hline
\end{tabular}

Source: Ministry of agriculture, forestry and food (1998, 2006a). 
data acquired trough aerial photography is most applicable. In the transition probability matrix, data from the cadastre of actual agricultural use of the ministry for agriculture, forestry and nutrition were applied. The temporal comparison was assured trough the data acquired for years 1998 and 2006 that have a comparable classification of land use categories. The spatial data was prepared, based on digital ortophoto maps on a scale of 1:5,000, based on aerial photographs on scales from $1: 15,000$ to $1: 25,000$, where a basic cell encloses 0.25 square meters. The cadastre of actual agricultural use distinguishes twenty four different land use categories. In scenario building only the nine land use categories that existed in the test area were included.

The digital ortophoto maps used for initial data acquisition were taken at different times, the oldest are from 1997, and the latest from 2004. During the scenario preparation, data for the test area was already hemstitched, based on the digital ortophotos from 2006. The time interval between both time acquisitions is only eight years apart, compared to scenarios that allow for intervals of fifteen years. However the time interval depends on the accessibility of the data. Briassoulis (2000) writes that by Markov models, which express the extrapolation of a certain time period on the future, the accuracy increases by the lengthening of the interval between the two data acquisitions.

In the presented case, apart from the importance of the time interval duration the spatial precision with respect the scale of the data is also important as we observe changes on relatively small areas. Despite the high spatial precision of the applied data some differences or inaccuracies can be noticed, which can be assigned to the digitalization procedure and on the assigning of homogenous areas based on the digital ortophotos. Differences between the data acquisition in 1998 and 2006 are obvious, for which we can not tell whether they originate from actual land use changes or only from different interpretations and also the precision of the data acquisition for both years mentioned (Table 2).

Changes of certain land use categories from 1998 to 2006 are quite in accordance with the general expectations of landscape changes trough time, such as an increase of the forests and of overgrown areas and a decrease of intensively used agricultural lands, fields and gardens. Some changes that are considered as expected, such as an increase of built and related areas displays a different trend in the test area, the built and related sites decreased from 1998 to 2006 by 66,507 square meters. The difference can be attributed to the more precise digitalization of the data in the year 2006, the assumption is also confirmed by a significantly larger number of polygons (for the land use category mentioned) defined in 2006 and in 1998. The comparison of the interpretation keys for both years shows that the category, Built and related sites in the 1998 acquisition, included also individual areas of permanent grassland and extensive orchards in the complex of the settlement or on the outskirts respectively and all the parcels regardless of their land use, if they were smaller than 1,000 square meters. The acquisition in 2006 was more precise and also the smaller parcels were assigned to their actual land use (as Fields and gardens or Permanent grassland), if farmers with proprietorship applied for agricultural subsidies. During both acquisitions, two land use categories were abandoned. Temporary grassland and Mountain pastures. Temporary grasslands were incorporated into the category Fields and gardens and Mountain pastures, into the category Permanent grassland. The land use category Fields and gardens, shows a significant decrease in the test area between the years of 1998 and 2006, by $48.43 \%$. This extensive decrease can be partly attributed to the guidelines for the acquisition of certain land use categories. Areas of Permanent grassland that were enclosed on three sides by fields were declared for Temporary grassland in the 1998 acquisition,

Table 2: The actual agricultural land use for the test area for the years 1998 and 2006 and the calculated changes of area with regard to specific land use.

\begin{tabular}{lrrr}
\hline Land use $\left(\mathrm{m}^{2}\right)$ & Year 1998 & Year 2006 & Change (\%) \\
\hline Fields and gardens & $570,427.21$ & $316,420.12$ & -48.43 \\
\hline Extensive orchards & $101,127.86$ & $110,284.32$ & +9.05 \\
\hline Permanent grassland & $16,945,663.42$ & $16,980,397.73$ & +0.20 \\
\hline Overgrown areas & $500,851.07$ & $677,216.96$ & +35.21 \\
\hline Uncultivated agricultural land & $404,382.52$ & $562,868.21$ & +39.19 \\
\hline Agricultural land with forest trees & $62,386.60$ & $34,839.45$ & -44.16 \\
\hline Trees and shrubs & $307,671.05$ & $146,574.96$ & -52.36 \\
\hline Forest & $62,800,071.31$ & $62,983,163.81$ & +0.29 \\
\hline Built and related sites & $2,435,285.04$ & $2,368,778.17$ & -2.73 \\
\hline
\end{tabular}

Source: Ministry of agriculture, forestry and food $(1998,2006 a)$. 
later when the category was abandoned they were assigned to Fields and gardens. In the 2006 acquisition as Fields and gardens, only areas that were actually ploughed were assigned, all other areas were assigned to the Permanent grassland category.

\subsection{Definition of transition probability matrix}

Transition probability matrix is based on the findings of land use changes in a certain time period, however the time period depends on the accessibility of data. The subsequent procedure required the definition of transition sequences conversion elasticity - the probability of transitions for each land use (Table 3).

The acreage and the number of areas for certain land use depend upon the precision of the data. As for the definition of transition probability matrix, the number of individual areas doesn't affect the results. The only important element is the adequate number of units for each land use category, which assures the representativeness of the probability of change for individual units within a certain land use category, especially if we only analyse a sample (Lawson, 1970). The assessment of transition refers to a basic unit - a raster cell that is assured by the use of raster data. The main characteristic of raster data is that only one land use can be assigned to each individual cell, and another important characteristic is the identical size of the raster cells. A raster cell was used as a basic unit also by Stadelmann and Weiss (2007), who declared the raster cell as the most appropriate basic unit for Markov chains when digital spatial data is used.

In the presented case of scenario building transitions between land use categories, which were calculated with the aid of the computer programme ArcInfo, based on the changes of the cell number for each land use category. Based on the known size

Table 3: Probable transitions of land use categories present in the test area (estimation).

\begin{tabular}{|c|c|}
\hline Present land use & Probable transitions in one sequence \\
\hline \multirow{3}{*}{ Fields and gardens } & $\rightarrow$ Fields and gardens \\
\hline & $\rightarrow$ Extensive orchards \\
\hline & $\rightarrow$ Permanent grassland \\
\hline \multirow{2}{*}{ Extensive orchards } & $\rightarrow$ Extensive orchards \\
\hline & $\rightarrow$ Overgrown areas \\
\hline \multirow{4}{*}{ Permanent grassland } & $\rightarrow$ Permanent grassland \\
\hline & $\rightarrow$ Uncultivated agricultural land \\
\hline & $\rightarrow$ Fields and gardens \\
\hline & $\rightarrow$ Overgrown areas \\
\hline \multirow{3}{*}{ Overgrown areas } & $\rightarrow$ Overgrown areas \\
\hline & $\rightarrow$ Forest \\
\hline & $\rightarrow$ Built and related sites \\
\hline \multirow{4}{*}{ Uncultivated agricultural land } & $\rightarrow$ Uncultivated agricultural land \\
\hline & $\rightarrow$ Overgrown areas \\
\hline & $\rightarrow$ Permanent grassland \\
\hline & $\rightarrow$ Built and related sites \\
\hline \multirow{3}{*}{ Agricultural land with forest trees } & $\rightarrow$ Agricultural land with forest trees \\
\hline & $\rightarrow$ Permanent grassland \\
\hline & $\rightarrow$ Built and related sites \\
\hline \multirow{2}{*}{ Trees and shrubs (line element) } & $\rightarrow$ Trees and shrubs \\
\hline & $\rightarrow$ Permanent grassland \\
\hline \multirow{2}{*}{ Forest } & $\rightarrow$ Forest \\
\hline & $\rightarrow$ Built and related sites \\
\hline \multirow{2}{*}{ Built and related sites } & $\rightarrow$ Built and related sites \\
\hline & $\rightarrow$ Overgrown areas \\
\hline Water & $\rightarrow$ Water \\
\hline
\end{tabular}


Table 4: Case of Permanent grassland category changes between the years 1998 and 2006.

\begin{tabular}{ll}
\hline Transitions from permanent grassland to other land use categories (1998-2006) & $\left(\mathrm{m}^{2}\right)$ \\
\hline Fields and gardens & $110,286.5$ \\
\hline Extensive orchards & $33,870.5$ \\
\hline Permanent grassland & $15,580,250$ \\
\hline Overgrown areas & 122,833 \\
\hline Trees and shrubs & $107,350.3$ \\
\hline Uncultivated agricultural land & $18,667.5$ \\
\hline Agricultural land with forest trees & $56,905.25$ \\
\hline Forest & 794,020 \\
\hline Built and related areas & $121,974.8$ \\
\hline Water & 679.75 \\
\hline Sum of transitions & $16,946,837.5$ \\
\hline
\end{tabular}

of the cells and number of changed cells the areas of the transitions were calculated. In the following table transitions for land use under the category Permanent grassland is presented.

The calculation of the transition probability matrix is performed by following procedure; the value for each cell in the matrix (Table 4) must be divided by the sum of the transitions in the same column. The probability transition matrix gives the probabilities of transitions from one land use category to others respectively and the probability not to change.

Table 4 presents the transitions for the case of Permanent grassland to other land use categories. Table 5 presents the calculated probabilities of the transition for each land use category based on the acreage of transitions in the eight year period from 1998 to 2006. The acreage of transitions was calculated by the computer programme ArcGIS 9.2, based on the number of changed cell values for each land use category. The matrix was calculated based on original data, no modifications were performed, only the incorporation of certain land uses were included, as a consequence of the abandonment of certain categories (between the acquisitions in 1998 and 2006).

Previously, some inconsistency and distinctions between the acquisition of data in 1998 and in 2006 with regard to actual agricultural land use were also mentioned. A suitable solution was the formation of the so called modified Markov chain, where the calculated transitions for every land use were verified and corrections based on interpretation keys comparison (Ministry of agriculture, forestry and food, 2006b) were performed Table 6).

The probabilities for the following land use categories were modified:

- Water: areas were excluded from further scenario building procedures as the probability of transitions for this land use is very low (or none at all) due to the lack of permanent water bodies in the region, with partially

Table 5: Transition probability matrix for land use changes between 1998 and 2006.

\begin{tabular}{llllllllllllll}
\hline & 2006 & $A$ & $B$ & $C$ & $C$ & $D$ & $E$ & $F$ & $G$ & $H$ & $I$ & $\Sigma$ \\
\hline$A$ & 0.34 & 0.00 & 0.66 & 0.00 & 0.00 & 0.00 & 0.00 & 0.00 & 0.00 & 0.00 & 1.00 \\
\hline$B$ & 0.00 & 0.45 & 0.40 & 0.00 & 0.02 & 0.00 & 0.03 & 0.06 & 0.03 & 0.00 & 1.00 \\
\hline$C$ & 0.01 & 0.00 & 0.92 & 0.01 & 0.01 & 0.00 & 0.00 & 0.05 & 0.01 & 0.00 & 1.00 \\
\hline$\check{C}$ & 0.00 & 0.00 & 0.21 & 0.52 & 0.04 & 0.00 & 0.00 & 0.22 & 0.00 & 0.00 & 1.00 \\
\hline $\mathrm{D}$ & 0.00 & 0.01 & 0.14 & 0.02 & 0.75 & 0.00 & 0.00 & 0.06 & 0.02 & 0.00 & 1.00 \\
\hline $\mathrm{E}$ & 0.00 & 0.00 & 0.65 & 0.09 & 0.00 & 0.19 & 0.00 & 0.04 & 0.00 & 0.04 & 1.00 \\
\hline $\mathrm{F}$ & 0.00 & 0.01 & 0.40 & 0.06 & 0.07 & 0.00 & 0.24 & 0.21 & 0.00 & 0.00 & 1.00 \\
\hline $\mathrm{G}$ & 0.00 & 0.00 & 0.01 & 0.00 & 0.00 & 0.00 & 0.00 & 0.99 & 0.00 & 0.00 & 1.00 \\
\hline $\mathrm{H}$ & 0.00 & 0.01 & 0.09 & 0.00 & 0.00 & 0.00 & 0.00 & 0.03 & 0.86 & 0.00 & 1.00 \\
\hline $\mathrm{I}$ & 0.00 & 0.00 & 0.12 & 0.00 & 0.20 & 0.00 & 0.00 & 0.09 & 0.00 & 0.58 & 1.00 \\
\hline
\end{tabular}

Comment: A - Fields and gardens, B - Extensive orchards, C - Permanent grassland, Č - Overgrown areas, D - Trees and shrubs, E - Uncultivated agricultural land, F - Agricultural land with forest trees, G - Forest, $\mathrm{H}$ - Built and related areas, I - Water. 
Table 6: Modified transition probability matrix for land use changes between 1998 and 2006.

\begin{tabular}{|c|c|c|c|c|c|c|c|c|c|c|}
\hline $1998-2006$ & A & B & $C$ & $\check{C}$ & D & $E$ & $F$ & G & $\mathrm{H}$ & $\Sigma$ \\
\hline A & 0.67 & & 0.33 & & & & & & & 1.00 \\
\hline B & & 0.45 & 0.40 & & 0.02 & & 0.03 & 0.06 & 0.03 & 1.00 \\
\hline C & 0.01 & & 0.92 & 0.01 & 0.01 & & & 0.05 & 0.01 & 1.00 \\
\hline$\check{C}$ & & & 0.21 & 0.52 & 0.04 & & & 0.22 & & 1.00 \\
\hline D & & 0.01 & 0.14 & 0.02 & 0.75 & & & 0.06 & 0.02 & 1.00 \\
\hline$E$ & & & 0.65 & 0.09 & & 0.23 & & 0.04 & & 1.00 \\
\hline $\mathrm{F}$ & & 0.01 & 0.40 & 0.22 & 0.07 & & 0.24 & 0.05 & & 1.00 \\
\hline G & & & 0.01 & & & & & 0.99 & & 1.00 \\
\hline $\mathrm{H}$ & & 0.01 & & 0.03 & & & & & 0.95 & 1.00 \\
\hline
\end{tabular}

Note: A - Fields and gardens, B - Extensive orchards, C - Permanent grassland, Č - Overgrown areas, D - Trees and shrubs, E - Uncultivated agricultural land, F - Agricultural land with forest trees, G - Forest, $\mathrm{H}$ - Built and related areas, I - Water.

karstic characteristics; changes shown in the matrix in table 4 can be attributed to the differences between the acquisition of the data.

- Built and related areas: the transition to Permanent grassland is less probable, so it can be partially attributed to the probability of no transition; transition to Forest is assigned to the category Overgrown areas, as the transition progresses by gradual overgrowth.

- Fields and gardens: a significantly extensive transition (two thirds of Fields and gardens to Permanent grassland in an eight year period) can be partially attributed to different interpretations for both the acquisition of the data and a possibility of assigning fields temporarily sown with grass to the category Permanent grassland; based on the evaluation and ascertainable extent of misinterpretations of Fields and gardens classification, half of the transition probability is assigned to the probability of no transition.

- Uncultivated agricultural land: probability of transition to Water is assigned to no transition due to the exclusion of land use water, from further scenario building.

- Agricultural land with forest trees: probability of transition to Forest is diminished and the difference is assigned to the probability of transition to Overgrowing areas.

For the values for transition probability of about 0.05 , the results weren't modified, as minor probabilities of change and minor misinterpretations and differences between both data acquisitions were considered permissible.

The forecasts of transitions for land use categories for the next fifteen years are calculated upon the following equation (vector named $\mathrm{p}(\mathrm{n})$ defines the probability of transition of the system to state $\mathrm{i}$ after $\mathrm{n}$ steps). As the probability distribution in matrix P depends only of the last preceding state, the use of Chapman-Kolmogorov equation is adequate (HudoklinBožič, 1999): $\mathrm{p}(1)=\mathrm{p}(0) * \mathrm{P}$

$\mathrm{p}(2)=\mathrm{p}(1) * \mathrm{P}=(\mathrm{p}(0) * \mathrm{P}) * \mathrm{P}=\mathrm{p}(0) * \mathrm{P}^{2}$

$\mathrm{p}(3)=\mathrm{p}(2) * \mathrm{P}=(\mathrm{p}(1) * \mathrm{P}) * \mathrm{P}=((\mathrm{p}(0) * \mathrm{P}) * \mathrm{P}) * \mathrm{P}=\mathrm{p}(0) * \mathrm{P}^{3}$

...

$\mathrm{p}(\mathrm{n})=\mathrm{p}(0) * \mathrm{P}^{\mathrm{n}}$

The transition matrix P presents the probabilities of transition from one state to other in a step (sequence) that is eight years long. For scenario building, we decided to take a fifteen year period, but due to mathematical characteristic of the equation the transitions for a sixteen year period could be calculated (two times eight years) so the following equation was used:

$\mathrm{p}(3)=\mathrm{p}(2) * \mathrm{P}=(\mathrm{p}(1) * \mathrm{P}) * \mathrm{P}=((\mathrm{p}(0) * \mathrm{P}) * \mathrm{P}) * \mathrm{P}=\mathrm{p}(0) * \mathrm{P}^{3}$

if the initial year for calculation is 1998 , respectively the equation:

$\mathrm{p}(2)=\mathrm{p}(1) * \mathrm{P}=(\mathrm{p}(0) * \mathrm{P}) * \mathrm{P}=\mathrm{p}(0) * \mathrm{P}^{2}$,

if the initial state is the year 2006. Due to the differences between both acquisitions, the transition values were calculated by both equations and the results compared. Calculations of the matrix were performed by the matrix calculator accessible at the Wims server (http://wims.unice.fr), the data was previously prepared with the aid of the computer programmes ArcInfo 9.2 and Excel.

\section{Results}

Table 7 presents the transitions for land use categories calculated with the use of two different equations. The first equation is based on the initial data from the year 1998; the second equation is based on initial data from the year 2006 and the adequate number of steps/ sequences shown as the exponent of step $p$. For further scenario building we used the results 
Table 7: Transitions of land use categories for the year 2022, according to two different procedur

\begin{tabular}{lrr}
\hline Acreage of land use categories $\left(\mathrm{m}^{2}\right)$ & $\mathrm{p}(2022)=\mathrm{p}(1998) * \mathrm{p}^{3}$ & $\mathrm{p}(\mathbf{2 0 2 2})=\mathrm{p}(\mathbf{2 0 0 6}) * \mathbf{P}^{2}$ \\
\hline Fields and gardens & $538,414.94$ & $422,835.88$ \\
\hline Extensive orchards & $61,042.68$ & $67,235.10$ \\
\hline Permanent grassland & $16,269,599.31$ & $16,401,922.75$ \\
\hline Overgrown areas & $557,455.35$ & $594,519.81$ \\
\hline Trees and shrubs & $630,175.89$ & $670,547.53$ \\
\hline Uncultivated agricultural land & 759.06 & $1,843.01$ \\
\hline Agricultural land with forest trees & 6947.70 & $11,649.14$ \\
\hline Forest & $63,911,861.74$ & $63,787,264.82$ \\
\hline Built and related areas & $2,601,429.04$ & $2,495,266.37$ \\
\hline Water & $/$ & $/$ \\
\hline Sum of acreage & $84,577,685.71$ & $84,453,084.41$
\end{tabular}

gained after the second equation, which was based on modified data (bolded column). The calculation based on recent data is principally more accurate as the methodology of the acquisition and the interpretation in the year 2006 was more precise, and consequently some inconsistencies were avoided, which were included in the data acquired in the year 1998.

Table 8 presents the changes for land use categories between the years 2006 and 2022, based on Markov chains. The increase of fields and gardens by one third ( 10 hectares) is evident from the results, a vast change can be partially explained with the inclusion of allotment gardens to the category, that are suppose to increase with the increase in built and related areas. The decrease of extensive orchards however could mean the opposite process from diminishing the areas of orchards due to the enlargement of settlements at the outskirts. The decrease is not as vast, as it only includes 4 hectares. The built areas are supposed to get bigger by 12 hectares. The decrease of permanent grassland ( $57 \mathrm{ha})$, overgrown areas ( $8 \mathrm{ha})$, uncultivated agricultural land ( $3 \mathrm{ha})$ and agricultural land with forest trees (13 ha) is expected and on the other hand an increase in the share of forest by $1.28 \%$ or roughly 80 hectares.
The calculated transitions or changes of land use categories were incorporated into the written scenario and complemented by development plans and guidelines for the test area and for the Idrija municipality (Bizjak, 2005; Bizjak, 2006). The scenario for test area of Godovič and Črni Vrh presents the situation of different land use categories in the test area after 15 years, and includes changes stated in developmental documents, for instance: the construction of the Godovic by-pass road, stimulated production and use of biomass, development of public services and trade. The written scenario and photomontages were used in the research that included all family farm owners from the test area. The research was aiming to establish the influence of scenario use on the attitudes and actions of the stakeholders. Scenario and photomontages are presented below.

\section{Scenario for the area of the local communities of Godovič and Črni Vrh after 15 years}

In the Godovic area the density of the settlement has increased. Remaining building lots inside the settlement areas and on

Table 8: Transitions for specific land use category from 2006 to 2022 after Markov chain method.

\begin{tabular}{lrr}
\hline Land use category & & Change of acreage (2006-2022) \\
\hline Fields and gardens & $\left(\mathrm{m}^{2}\right)$ & $(\%)$ \\
\hline Extensive orchards & $+106,415.76$ & 33.63 \\
\hline Permanent grassland & $-43,049.22$ & -39.03 \\
\hline Overgrown areas & $-578,474.98$ & -3.41 \\
\hline Trees and shrubs & $-82,697.15$ & -12.21 \\
\hline Uncultivated agricultural land & $+107,679.32$ & 19.13 \\
\hline Agricultural land with forest trees & $-32,996.45$ & -94.71 \\
\hline Forest & $-134,925.82$ & -92.05 \\
\hline Built and related areas & $+804,101.01$ & 1.28 \\
\hline
\end{tabular}


the outskirts have been built up by family houses; the industrial area has developed and extended. Godovič has a by-pass road; the Ljubljana-Kalce road has been adapted to allow for greater traffic velocities. In the village Črni Vrh, several new residential buildings were constructed. In other smaller villages some new residential and farm buildings were constructed, older buildings are being adapted and renovated. The total increase of built areas is roughly 10\%. In Godovič and Črni Vrh smaller services and supply centres have been opened, including shops, restaurants, banking services and a post office. In open spaces, overgrown areas have decreased by roughly $10 \%$, only smaller sections of agricultural land (about 10\%) that weren't cultivated remain so. The maintenance and cleaning of overgrown areas is mostly in order to exploitation the biomass sector. Grassland areas only decreased by roughly $3 \%$ their size is maintained by mowing and its use for pasture. The forest areas have increased by roughly $1 \%$. Fields and gardens, which include house gardens are more variable and could increase by up to $30 \%$. Extensive orchards have decreased by $30 \%$, which can be attributed to the residential construction both inside and on the outskirts of these settlements.

\section{Conclusion}

The presented case of the scenario building based on a Markov chains describes the application of the method which is more frequently used in forecasting the changes in a certain time period, where the data has no spatial characteristics. The results of the method application are the calculated probabilities for change. On the basis of transition probability, the spatial extent or the acreage expected to change can be estimated. Dealing with spatial data; normally the most important issue is the spatial distribution or allocation of the expected changes, e.g. where most probably the grassland will be left to overgrow or which area will most probably be turned into building sites? Calculations based on Markov chains do not include allocations of this kind. As Kovačič et al. (2007) also

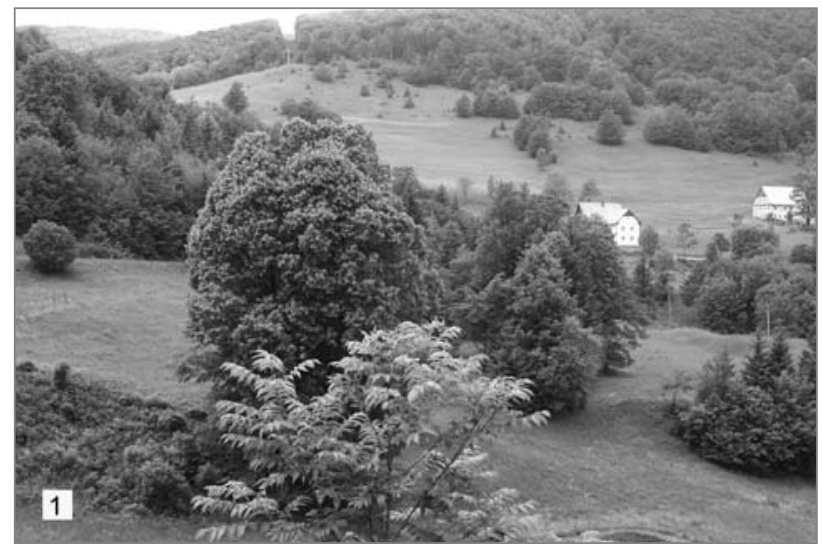

established (in research performed by Idrisi computer programme), for the allocation of transitions the programme needs to be complemented by certain rules or models with defined spatial attractiveness and restrictions for each land use. For the same reason Tappeiner (2007) used scenarios from a stakeholder workshop to complement the scenario based on Markov chains in order to allocate the landscape changes in a certain area. Markov chain method is relatively easy to use and can be applied in analysis of spatial or time dynamics for different phenomena. The most important restriction of its use for spatial data analysis mentioned by several authors (Lawson, 1970; Mežan, 1995; Gantar, 2009) is the accessibility of the suitable and comparable spatial data with an appropriate time line. The quality of the data influences the precision of the predicted probability of changes the greatest.

The Markov chain method has turned out to be applicable and explicit for use in a scenario building procedure, despite the mentioned deficiency or inability to automatically allocate changes and the demands for a certain form and contents of the required data. On the contrary, the easier method of linear extrapolation showed to be unsuitable for the purpose of scenario building. The calculations based on the Markov chain method have become quite acceptable and probable for several land use categories. For some of the land use categories, where the results gained differed from those that were expected, forecasts can be adjusted by the notion of the reasons for deviations, such as the differences in the interpretation of the initial data and some errors that can be verified by additional data and field surveys. The scenario prepared for the test area Godovič and Črni Vrh required some adjustment of the final results. Calculations based on Markov chains were complemented by notable development objectives for the area, and presented as a written report illustrated by photographs of the present state of affairs and photomontages of a scenario. The scenario case presented in the article was not prepared just to introduce probable landscape changes, but was primarily purposed as a tool for the research of scenario influences

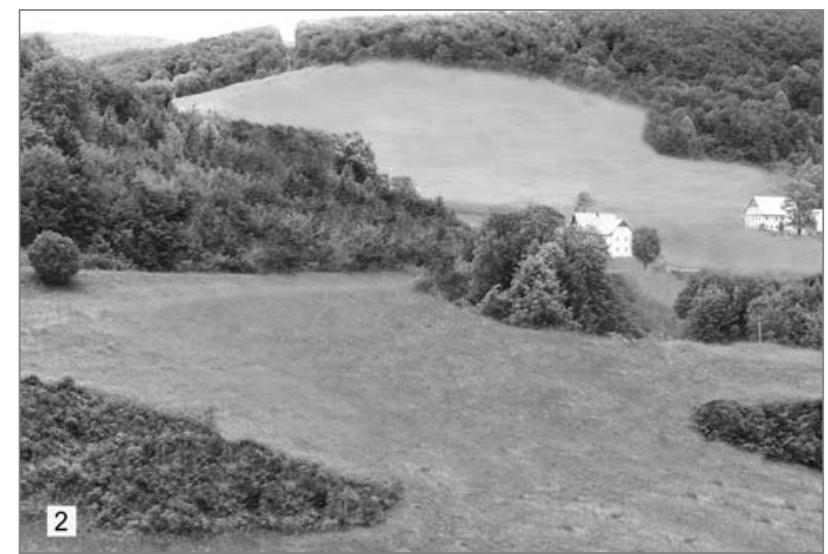

Figure 2: 1 - photography of the situation in year 2006; 2 - photomontage of the scenario (photo: Damjana Gantar). 
on the attitudes and actions of stakeholders that took part in the research. For the use as a research tool, also an intuitively prepared scenario would probably meet the demands; however the scenario based on the Markov chain method is considered more objective. During the research we also established that most of the participants that actually live and maintain the landscape of the test area pictured themselves with similar future landscape changes, as those that were presented in the scenario.

Damjana Gantar, Landscape Architect

Urban Planning Institute of the Republic of Slovenia, Ljubljana,

Slovenia

E-mail:damjana.gantar@uirs.si

\section{Notes}

[1] Ph.D. thesis, mentor: assist. prof. dr. Mojce Golobič, University of Ljubljana, Biotechnical faculty, Department of Landscape Architecture.

\section{References}

Basharin G. P., Langville A. N., and Naumov V. A. (2005) The life and work of A. A. Markov. Available at: http://decision.csl.uiuc. edu/ meyn/pages/Markov-Work-and-life.pdf (Date accessed 10. 5. 2007)

Briassoulis, H. (2000) Analysis of land use change: Theoretical and modelling approaches. Available at: http://www.rri.wvu.edu/WebBook/Briassoulis (Date accessed 6. 6. 2007).

Bizjak, R. (2005) Razvojni program območja doline reke Idrijce. Idrija, Studio 3, d. o. o., Koda, d. o. o, Icra, d. o. o.

Bizjak, R. (2006) Strokovne podlage za poselitev občine Idrija. Idrija, Koling, d. o. o., Občina Idrija.

Gantar, D. (2009) Scenarij razvoja kulturne krajine kot dejavnik spreminjanja stališč in ravnanja deležnikov. Ph.D. thesis. Ljubljana, Univerza v Ljubljani, Biotehnika fakulteta, Oddelek za krajinsko arhitekturo.

Hudoklin-Božič, A. (1999) Stohastični procesi. Kranj, Moderna organizacija.

Jamnik, R. (1987) Verjetnostni račun. Ljubljana, Društvo matematikov, fizikov in astronomov SRS, Zveza organizacij za tehnično kulturo Slovenije.

Kovačič, B., Kranjc, M., Primožič, T. Sajovic, T., and Tomšič, A. (2007) Uporaba Markovskih verig in podpore odločanja na primeru Slovenije. Research report. Ljubljana, University of Ljubljana, Filozofska fakulteta, Oddelek za geografijo.

Lawson, B. R. (1970) An application of Markov Chains to an analysis of the growth and decline of settlements in the Ljubljana metropolitan area. American-Yugoslav project in regional and urban planning studies. Ljubljana, Urbanistični inštitut SR Slovenije.

Mežan, U. (1995) Napovedovanje poškodovanosti gozdov z uporabo modela markovskih verig. Diploma. Ljubljana, Univerza v Ljubljani, Biotehniška fakulteta, Oddelek za gozdarstvo.
Ministry of agriculture, forestry and food (1998) Kataster dejanske rabe kmetijskih zemljišč (RABA). Izpis iz baze podatkov. Ljubljana.

Ministry of agriculture, forestry and food (2006a) Kataster dejanske rabe kmetijskih zemljišč (RABA). Izpis iz baze podatkov. Ljubljana.

Ministry of agriculture, forestry and food (2006b) Interpretacijski ključ. Podroben opis metodologije zajema dejanske rabe kmetijskih in gozdnih zemljišč. Ljubljana.

Omladič, V. (1993) Application of interactive Markov models in the dynamics of social systems. Available at: http://www.sisplet.org/index.php? $\mathrm{fl}=28 \mathrm{lact}=18 \mathrm{bid}=197 \&$ avtor $=172 \&$ parent $=30$ (Date acces sed 7. 5. 2007)

Shearer, A. W. (2005) Approaching scenario based studies: Three perceptions about the future and considerations for landscape planning. Environment and Planning B: Planning and Design, 32(1), pp. 67-87.

Shoemaker, P. J. H. (1993) Multiple scenario development: Its conceptual and behavioral foundation. Strategic Management Yournal, 14(3), pp. 193-213.

Stadelmann, G., and Weiss, M. (2007) Modelierung der zukünftigen Landnutzung in der Surselva. Zürich, Eidgenössische Technische Hochschule, Swiss Federal Institute of Technology.

Steinitz, C., Arias Rojo, H. M., Basset, S., Flaxman M., Goode, T., Maddock III, T., et al. (2003) Alternative futures for changing landscapes. The Upper San Pedro river basin in Arizona and Sonora. Washington D.C., Island Press.

Tappeiner, U. (2007) Land use change in the European Alps: Effects of historical and future scenarios of landscape development on ecosistem services. Available at: http://epub.oeaw. ac.at/0xc1aa500d_0x0016f3a1.pdf (Date accessed 29. 1. 2009)

Veeneklaas, F. R., and van den Berg, L. M., (1995) Scenario building: Art, craft or just a fashionable whim? In: Schoute, J. F. T., Finke, P. A., Veeneklaas, F. R., and Wolfert, H. P. (ed.): Scenario studies for the rural environment, pp. 11-13. Dordrecht, Kluwer academic publishers. 